\title{
Original Research \\ Properties of Coal Gasification Wastes Essential to Determining Their Impact on the Environment
}

\author{
Radosław Pomykala*, Maciej Mazurkiewicz \\ AGH University of Science and Technology, Faculty of Mining and Geoengineering, \\ Department of Environmental Engineering and Mineral Processing, Mickiewicza 30, 30-059 Cracow, Poland \\ Received: December 18, 2014 \\ Accepted: April 19, 2015
}

\begin{abstract}
Gasification is playing an increasingly significant role in thermal processing. The different types of solid waste generated in these processes should ultimately be treated as by-products and be used in various industries (such as fly ash from coal combustion, for example). However, studies of waste properties are needed to determine real and potential impact on the environment. The scope of our tests depends on methods and directions of planned use of waste. Our paper presents and discusses the test results of waste generated in research installations: one in a large laboratory and the second in a pilot plant. The wastes are derived from the process of direct combustion, direct gasification, and the two-stage process of coal gasification with char formation followed by combustion. All installations are based on the fluidized bed, with two hard coals and lignite used as fuel. Tested materials belong to two groups: fly ash and bottom ash. Research of the waste properties was conducted in the field of grain size distribution, chemical composition, content of combustible leaching of chemical contaminants, and radioactivity. Analysis of the results was carried out both in terms of existing legislation and also related to a comparison of properties of materials from single-stage and two-stage thermal processing.
\end{abstract}

Keywords: fly ash, gasification waste, leaching, radionuclides, fluidization bed

\section{Introduction}

Each thermal processing of solid fuels, including coal, is associated with the generation of waste/solid by-products stemming from the mineral matter contained in the fuel. The most common process of this type is, of course, coal combustion, and solid waste generated in this way is predominantly fly ash. Over the last decades fly ash, and more broadly energy wastes, have stopped being considered mainly as burdensome waste, problematic to disposal and a potential risk to the environment, and have begun to be more widely regarded as a valuable by-product used in many industries. However, to make this possible it was necessary to start conducting in-depth and systematic research to determine the possible adverse impact on the environment.

*e-mail: rpomyk@agh.edu.pl
Adverse impacts of ash may involve a number of elements of the environment, including in particular the atmosphere, water, and soil, as well as live nature, including humans. An important problem may be dusting of particulates like fly ash, both during their manufacture and transport. The risk of water and soil contamination is mainly related to the possibility of leaching of chemical contaminants, including heavy metals [1]. Properties and composition of the eluates depend primarily on the fuel properties of the source [2]. The problem of leaching of chemical contaminants can concern both the same ash, as well as materials and building components containing them, such as embankments, road substructures [3], or other places of use and disposal of such materials. Another important part of the environmental assessment is to determine the possible radiation emission from the ashes, making it necessary to determine the content of radionuclides $[4,5]$. 
In most cases, the adverse environmental impact of ash can be avoided. It is necessary, however, to have full information about the key parameters of such materials. This concerns information about the kinds and basic physico-chemical properties of the ash, which depends on both the properties of the fuel and the type of thermal processing technology. The last several years have seen an increase in the amount of ash from plants based on fluidized bed boilers. Waste from such installations can be divided into two basic groups: fly ash, in which most of the particles are smaller than $0.1 \mathrm{~mm}$, and bottom ash, where sand fraction predominates $[6,7]$. A common feature of both types of ash is alkaline reaction, and the share of flue gas desulfurization process (usually calcium compounds).

Beside combustion, in recent years the gasification process has been playing an increasingly important role in the field of thermal processing of solid fuels [8-10]. So far, Poland does not possess any of this type of installation on an industrial scale. Advanced research and development in this area is being conducted with the use fluidized bed reactors. The direct product of coal gasification in this installation is a char, which then was burned in a fluidized bed boiler.

As a result of these operations and tests, solid wastes have been produced in the form of fly and bottom ash. The analysis properties of this ash in light of the potential environmental risk is the subject of this article.

\section{Materials}

The test materials were derived from the thermal processing of three different coals: lignite and two hard coals. The main series of material samples for testing are the result of two thermal processes of coals. In the first stage two types of hard coal and one lignite were gassified at atmospheric pressure in a pilot fluidized bed reactor belonging to the Institute for Chemical Processing of Coal (IChPW) in Zabrze, Poland [11-13]. In this process, semiproducts (char coals) were formed containing carbon in amounts from $40 \%$ to about $60 \%$. In the next step char coals were combusted in a fluidized bed boiler (the largelaboratory scale), belonging to the Technical University of Czestochowa (PCz) [14]. Furthermore, in the PCz installation the same coals were directly combusted, from which char coals were prepared. In these two ways, 12 samples of ashes were produced (six bottom and six fly), while six were derived from coal combustion and six from char coal combustion. Designation of samples is as follows: the first letter indicates the type of source coal (B - lignite from Belchatow Mine, J - hard coal from Janina Mine, and W hard coal from Wieczorek Mine), the second, directly combusted material: W - coal (or lignite) and $\mathrm{K}$ - char. The third letter indicates the type of ash: L - fly ash and D - bottom ash. For example:

BKD - bottom ash from combustion of char from lignite 'Belchatow' gasification

WKL - fly ash from combustion of char from 'Wieczorek' hard coal gasification

JWD - bottom ash from combustion of 'Janina' hard coal
The second group of materials represents two samples: fly ash (FA3) and bottom ash (BA1) produced during the tests of direct gasification process of lignite in the $\mathrm{PCz}$ installation, working then as a fluidized bed gasifier [14].

Coals of which ash formed (directly or indirectly) may be characterized by several important parameters such as ash content in the dry matter $\left(\mathrm{A}^{\mathrm{a}}\right)$ and the content of: the volatiles $\left(\mathrm{V}^{\mathrm{daf}}\right)$, carbon $\left(\mathrm{C}^{\mathrm{dar}}\right)$, hydrogen $\left(\mathrm{H}^{\mathrm{dat}}\right)$, and sulfur $\left(\mathrm{S}^{\mathrm{dat}}\right)$ in terms of pure coal material. These values for coal $\mathrm{B}$ are: $\mathrm{A}^{\mathrm{a}}=19.9 \%, \mathrm{~V}^{\mathrm{daf}}=57 \%, \mathrm{C}^{\mathrm{daf}}=67.1 \%, \mathrm{H}^{\mathrm{daf}}=1.1 \%, \mathrm{~S}^{\mathrm{daf}}=1.0 \%$, for coal J: $\mathrm{A}^{\mathrm{a}}=12.8 \%, \mathrm{~V}^{\mathrm{daf}}=42.1 \%, \mathrm{C}^{\mathrm{daf}}=79.6 \%, \mathrm{H}^{\mathrm{daf}}=5.5 \%$, and $\mathrm{S}^{\mathrm{daf}}=4.0 \%$, and for coal $\mathrm{W}: \mathrm{A}^{\mathrm{a}}=13.0 \%, \mathrm{~V}^{\mathrm{daf}}=38.2 \%$, $\mathrm{C}^{\mathrm{daf}}=83.8 \%, \mathrm{H}^{\mathrm{daf}}=5.8 \%$, and $\mathrm{S}^{\mathrm{daf}}=1.71 \%[15,16]$.

\section{The Scope and Methods of Wastes Testing}

Energy waste impact on the environment is a very broad issue and over the years has been described in a number of publications, also as a compilation and review form, in probably every country where the waste is produced. It is worth noting that this problem is still the subject of evaluations, studies and investigations due to the great diversity of this type of material, as well as a multitude of directions and conditions of use or disposal [6, 17-27]. Based on previous experience in research of waste from the combustion of coal and other waste materials, the physical and chemical properties of waste/by-products of coal gasification were identified, which is important for determining the potential environmental risk. This group includes grain composition, leaching of chemical contaminants, and content of radionuclides, and - to a lesser extent - chemical composition and content of combustible parts.

\section{Grain Composition, Dust Fraction Content}

Detailed determination of particle size distribution of waste, part of the basic research necessary for the characteristic of the material, is performed before deciding on the direction of waste management. This test may be useful to assess the possible negative impact of waste on the environment, especially on the atmosphere and living organisms, including humans. This is particularly important in the case of materials with a high proportion of the particulate fraction, less than $63 \mu \mathrm{m}$. The content of the respirable fraction $(<3 \mu \mathrm{m})$ is especially important for the health and safety of people and animals. Such grains can enter the lungs of living organisms and accumulate there. Knowing the size distribution of the material, it is possible to determine the source and extent of possible contamination, and undertake appropriate precautions to prevent dust emissions during storage and transport, or specific methods of utilization.

Particle size distribution of waste from coal gasification depends mainly on the location of their formation, processing conditions, and type of installation. The highest content of the particulate (dust) fractions shows the ash captured in gas purification systems, especially those derived from the system based on the fluidized bed. 
The particle size of the gasification by-products depends mainly on the type of installation where the byproducts are generated. The biggest content of slit fraction is shown in the ash captured in gas purification systems, especially from the installations based on a fluidized bed.

\section{Radioactivity (Radionuclide Content)}

The concentration values of natural radioactive isotopes are given according to ITB regulations (Warsaw, No. 234, 1995). The measurements have been conducted with the use of a gamma radiation spectrometer [28]. The methods and equipment must meet the requirements of the Council of Ministers of 2 January 2007 (Journal of Laws, No. 4 Item 29 ) on the requirement for the natural radioactive isotopes in minerals and materials for civil buildings, industrial waste used in building industry, and the controlled content of these isotopes. According to the regulation mentioned above the values of indicators $f_{1}$ and $f_{2}$ can go above $f_{1}=1$ and $\mathrm{f}_{2}=200 \mathrm{~Bq} / \mathrm{kg}$.

The regulation PN-G-11011:1998 describes the maximum content of radionuclides in materials used for backfill in underground mining. According to this the specific activity of radioactive isotopes (radium isotope ${ }^{226} \mathrm{Ra}+{ }^{228} \mathrm{Ra}$ ) should not be above $1 \times 10^{4}[\mathrm{~Bq} / \mathrm{kg}]$.

The conducted literature research did not reveal any information on the increased radionuclide content in the waste from coal gasification. Nevertheless, such research for ash both from combustion and gasification are of common practice and inseparable parts of their characteristics for both utilization and landfill [4, 5, 29-33].

\section{Unburned Carbon Content}

In gasification by-products sometimes the grains of char (the not totally processed coal) may occur. This may cause inconvenience in the management of these materials, as well as the storage (landfill) and utilization - hence there is a risk of uncontrolled oxidation and thus the emission of gases into the atmosphere. Such problems have appeared in the past mainly in the case of extractive waste in coal mining. Nowadays, high carbon content in an ash is very rare because of the limitation in management of these waste and the effectiveness of fuel use. In the case of systems in industrial scale the occurrence of the higher content of flammable parts in the ash proves the faults of some stage in the process of thermal processing and usually causes immediate preventative actions. Content of unburnt carbon was determined indirectly on the basis of loss on ignition tests at 700 and $1000^{\circ} \mathrm{C}$.

\section{Chemical Composition}

The chemical composition of the by-product from coal gasification depends on many factors, mainly the chemical composition of the fuel itself but also the additives used (e.g. the ones that increase or decrease the temperature of ash melting), and sorbents or any material from the fluidized bed (in the case of the reactor of this type).
Among the energy wastes from the combustion processes available on the market the products of fume desulphurization are of significant meaning in the assessment of environmental hazards. Particularly noteworthy are the results of studies on the content of calcium oxide, sulphur oxide, and heavy metals.

The tests were conducted with use of spectroscopy (ICP-AES), and mass (ICP-MS) emission methods, as well as an energy-dispersive $\mathrm{X}$-ray fluorescence (EDXRF) spectrometer X-5000.

Chemical composition testing is of auxiliary character, while discussing the environmental hazard, allowing for a preliminary assessment of the potential in range of leaching of chemical contamination, and showing the possible direction of their management. This may be required when the specific methods of the waste use is applied. Due to the lack of relevant provisions regarding this kind of waste, content of heavy metals in the ashes compared with their permissible content determined for soils in industrial areas is of significant importance.

\section{The Leaching of Chemical Contamination and Reaction}

Tests on the leaching of chemical contamination is the basic type of test that allows us to determine the possible impact of waste on water, soil, and organisms. The objective of these tests is to determine the amount of contamination that can penetrate the environment as a result of water operating. Water is a basic media for contamination by the waste managed both by storage and utilization, including that used in land engineering applications such as heaps or earthwork - either as components of building materials or as objects such as roads, houses, etc. The experience gained so far in Poland and elsewhere underlines the fact that the leaching test is significant for determining the ways and methods of dealing with the products of thermal processing due to the possibility of long-lasting migration of the contamination in the environment $[25,34,35]$.

The range of tests covers mainly the content determination of the chlorides and sulphates, ChZT, cyanide, sodium, potassium, and many of the heavy metals such as chrome, zinc, cuprum, nickel, lead, or cadmium. The tests were conducted with use of spectroscopy (ICP-AES) and mass (ICPMS) emission methods.

The determination of $\mathrm{pH}$ is essential both to assess the influence on the surface and underground water, and on living organisms. The increased value of $\mathrm{pH}$ (alkaline) may be caused by the use of the additives modifying the properties and that are used to capture sulphates.

\section{The Tests Results}

\section{Grain Composition}

The potential environmental hazard relating to particle size distribution of the materials is associated primarily with the risk of dust. Therefore, the conducted research 
concentrated mainly on fly ash. The results of grain compositions of fly ash derived from the char combustion and ash obtained from lignite gasification (FA3) are shown in Fig. 1 and marked by black lines. Grey lines represent comparative materials derived from combustion of hard coal (FFC) and lignite (FFL) in industrial power plants with fluidized bed boilers, as well as fly ash from hard coal combusted in a power plant with a pulverized boiler [36].

It should be underlined that the grain distribution of fly ash from the combustion of hard coal chars (WKL and JKL) is very similar to the fly ash from the coal combustion in commercial power plant with fluidized bed boiler (FFC), but differs from grain size distribution curve of the fly ash from coal combustion in industrial pulverized boiler (FPC). Differences in grain composition of fly ash originating from lignite are more noticeable. The materials derived from research installation (FA3, BKL) shows bigger content of smaller grains than the ashes from commercial power plants - both based on lignite (FFL) and hard coal (FFC).

The content of grains smaller than $63 \mu \mathrm{m}$ was, in the studied fly ash above $70 \%$, what shows the serious risk of dustiness in the case of not obeying safety regulations. The content of the respirable dust is also significant: the fraction $<3 \mu \mathrm{m}$ is between $5 \%$ and $15 \%$. The results obtained do not differ greatly from results for typical fly ash from lignite and coal combustion in industrial boilers with a fluidized bed [37].

\section{Radioactivity (Radionuclide Content)}

Research has been conducted with the use of a semiconductor gamma radiation spectrometer owned by the Department of Physics and Nuclear Techniques AGH, according to the CoM ordinance of 2 January 2007 on regulating the amount of natural radioactive isotopes in raw materials used for civil and agricultural buildings, and in industrial waste used in the building industry and the controlling of isotope content. This document defines the limit values for parameters $f_{1}$ and $f_{2}$ as follows: $f_{1} \leq 1 \pm 20 \%$ and $\mathrm{f}_{2} \leq 200 \mathrm{~Bq} / \mathrm{kg} \pm 20 \%$.
Radionuclide content in the tested samples does not exceed the allowance limits for building materials (Table 1). In most, the content of the radionuclides in the tested ash was lower than typical for of such materials $[5,6,30,38$, 39]. However, in the case of fly ash from ' $J$ ' coal the results for $\mathrm{f}_{1}$ reach the allowed limits. In such a situation additional tests should be conducted for different samples taken at intervals.

\section{The Content of Unburned Carbon}

Among the tested samples, some fly ash taken from the large laboratory installation showed a significant amount of unburned coal (Table 1). This appears to be due to low effectiveness of the fluidized combustion process for two hard coals and chars from gasification of this coal. It was probably due to a mismatch of process parameters to properties or the fuels. Such situations occur more often in laboratories rather than in industrial installations. Nevertheless, this raises a lot of problems in the use of such waste [40-43]. The content of unburned coal reaching amounts greater than $2 \%$ is rather worrying, and content above $8 \%$ eliminates the ash from application in building or mining industries, without additional processing.

In the case of bottom ash and fly ash from lignite the amount of unburned coal was at a much lower level.

\section{Chemical Composition}

Tests on chemical composition of fly ash are of basic importance for determining its properties while thermal processing, and to indicate the possible sources of increased leaching of chemical contamination. The chemical composition of ash from char combustion (without loss on ignition) is shown in Table 1. The increased value of $\mathrm{SiO}_{2}$ in the bottom ash (WKD, BKD) indicates the presence of the material from the fluidized bed - in this case quartz sand.

The content of specific heavy metals in the studied material is diverse (Table 1). Therefore, for the evaluation of the results three factors were taken into account whose

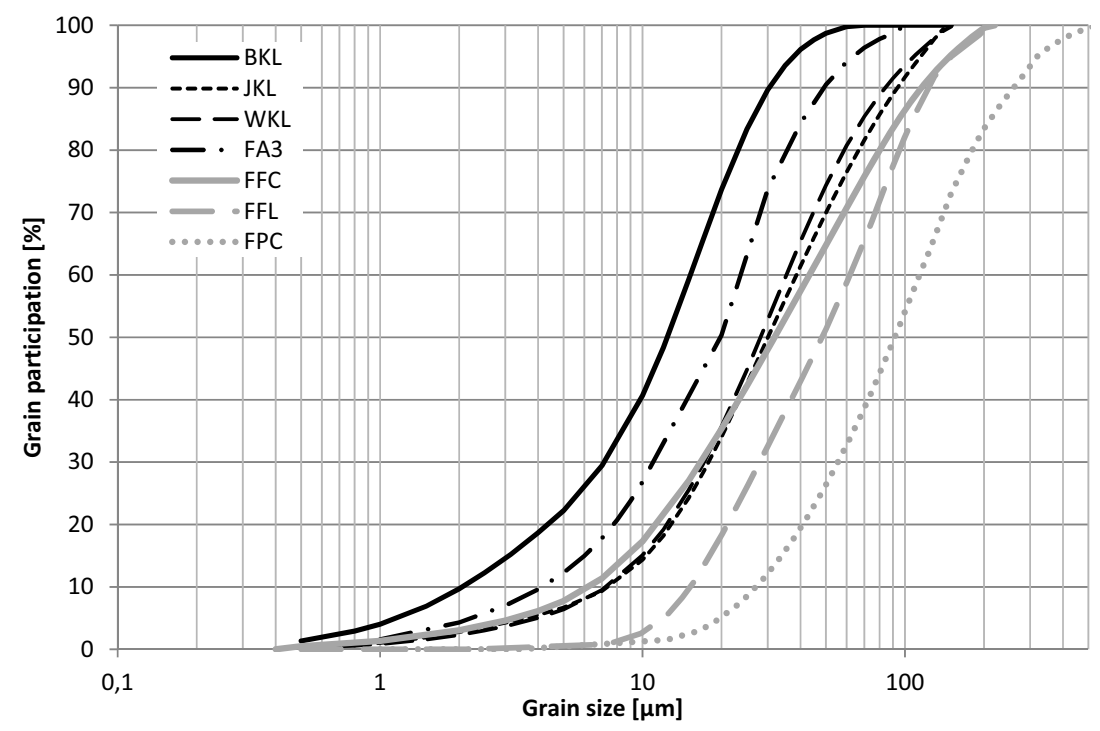

Fig. 1. Grain-size distribution of ash from char combustion. 


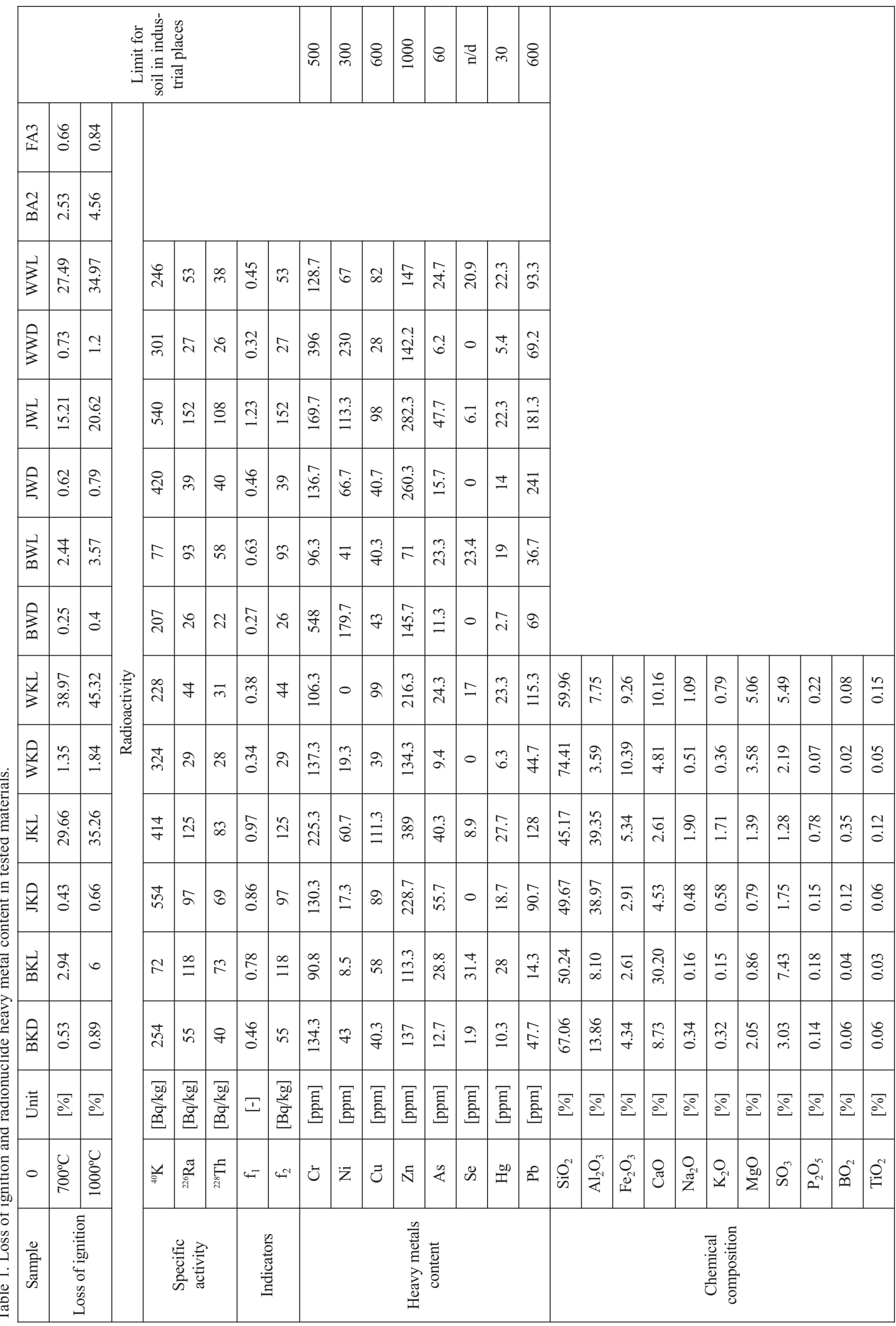


potential impact was recognized to be the most important: the type of coal from which they are derived, the type of ash (fly and bottom), the process of their preparation (direct coal combustion or combustion of char resulting from coal gasification), and combinations thereof.

The highest contents of chromium $(\mathrm{Cr})$ and selenium (Se) were recorded in the ash derived from coal (lignite) Belchatow, copper $(\mathrm{Cu})$, zinc $(\mathrm{Zn})$, arsenic (As), mercury $(\mathrm{Hg})$, and lead $(\mathrm{Pb})$ in ash from the coal ' $\mathrm{J}$,' and nickel $(\mathrm{Ni})$ in the ash from coal 'W.' Studies have found generally higher contents of copper $(\mathrm{Cu})$, selenium $(\mathrm{Se})$, and mercury $(\mathrm{Hg})$ in the fly ash as compared to the bottom ash. However, for all heavy metals a significant role was also played by other factors. For each metal, the situation was as follows:

- In the case of chromium, its content in all ash from coal 'J' was similar, but significantly bigger differences were observed for the remaining ash. Definitely the largest chromium content was noted for bottom ash from combustion of coal samples (BWD and WWD).

- The highest nickel content was recorded in bottom ash. Furthermore, it is generally more noticeable content of this element in samples from the direct combustion of coals compared to the combustion of chars.

- Higher average value of copper $(\mathrm{Cu})$ were found in fly ashes and in all the wastes from the combustion of chars, regardless of the type of coal from which they originated.

- The contents of $\mathrm{Zn}$ and As are slightly differentiated in particular types of waste and largely dependent on the origin of the waste (type of coal). However, the arsenic content is generally lower in the bottom ash (except for waste from the combustion of char ' $\mathrm{J}$ ').

- Selenium is practically non-existent in bottom ash. The highest content of Se was measured in fly ash from hard coals (coals ' $J$ ' and 'W').

- Significantly higher mercury content was found in fly ash as compared to bottom ash, as well as in wastes from the combustion of chars.

- Average lead content was greater (for samples from 'B' and ' $\mathrm{J}$ ' - significantly greater) in materials from the combustion of coals, and generally in bottom ash.

Despite the differences claimed only in one case, the copper content in the bottom ash BWD acceptable limits laid down for soils from industrial sites was exceeded. However, the high diversity of the results indicates a need to also consider the type of thermal processing, in addition to the type of coal and ash in future studies of the content of heavy metals in generated wastes.

\section{Leaching of Chemical Contamination}

The results of testing on leaching of chemical contamination of ash from coal and char combustion are shown in Table 2. The table contains a column that shows the limit values for eluates of waste used in backfilling technologies in hard coal mining. The requirements are consistent with the regulation of the Ministry of the Environment of 24 July 2006 on the condition that it should be applied while intro- ducing wastewater into the water or soil, and on the substances harmful to the aquatic environment (Polish Journal of Laws 2006 No. 137 Item 984).

The preliminary analysis of the results shows few examples of the values above the allowed limits. This refers to $\mathrm{pH}$ and the content of sulphates. Such a situation occurs frequently, especially in the case of ash from coal combustion in commercial fluidized bed installations or ash containing products from fume desulphurization [6, 37, 44]. Such materials are approved for use in the mining industry by separate decisions of the State Mining Authority.

The obtained results are rather differentiated and, to a great extent, depend on the kind of fuel they originate from. They do not allow us to clearly state the influence of the thermal processing on the leaching of chemical contamination. In searching for general tendencies, the direct comparison has been conducted on the same kinds of waste coming from combustion of coal (sample 'W') or char from coal (sample ' $\mathrm{K}$ '). Moreover, the analysis has been conducted of the average values calculated basing on dependence on the kind of fuel combusted (coals or chars from gasification), the type of waste (fly ash ' $\mathrm{L}$ ' or bottom ash ' $\mathrm{D}$ '), and both of these indicators simultaneously. The following relations and tendencies have been observed:

- No matter of the type of fuel, significantly higher values of leaching both for cations and anions have been observed for eluates of fly ash in comparison with bottom ash.

- In almost all cases ash ' $\mathrm{K}$ ' showed lower $\mathrm{pH}$ than ash ' $\mathrm{W}$ '; the biggest differences refer to pairs JKD-JWD and WKD-WWD originating from hard coals.

- Higher values of cations, mainly heavy metals, have been observed in eluates of ' $\mathrm{K}$ ' samples. This refers to potassium, cadmium, and copper for all samples, nickel for samples based on hard coals, and mercury in the case of samples from ' $\mathrm{J}$ ' ash. However, it should be noted that the absolute value of these contaminations stays at a low level.

In other cases direct comparisons do not allow for more general conclusions.

\section{Conclusions}

The research has been conducted on waste from the direct coal combustion process in large-laboratory scale installations, combustion of char from coal gasification in a pilot installation, and direct gasification of coals. Both installations are based on fluidized bed technology. Three types of coals were used for testing: two hard coals and lignite.

The main aim of the study was to characterize this type of waste to determine the potential environmental risk in case of their future development and use. Moreover, attention has been paid to the comparison of the properties of ash from coal and char combustion.

Most of the materials meet the requirements on the environmental impact with regard to the two most impor- 


\begin{tabular}{|c|c|c|c|c|c|c|c|c|c|c|c|c|c|c|c|c|}
\hline \multirow[b]{2}{*}{ 司 } & \multirow{2}{*}{ 音 } & & 衰 & 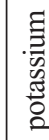 & 号 & 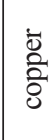 & 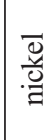 & $\underset{\mathscr{\Xi}}{\mathscr{\Xi}}$ & 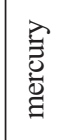 & 章 & 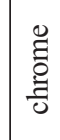 & 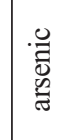 & 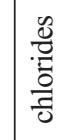 & 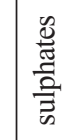 & & \\
\hline & & & $\stackrel{\infty}{~}$ & $\infty$ & $\stackrel{\circ}{i}$ & $\stackrel{2}{0}$ & $\stackrel{\leftrightarrow}{i}$ & $\stackrel{2}{0}$ & 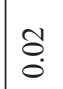 & $\overrightarrow{0}$ & $\tilde{o}$ & ปี & 8 & 8 & & \\
\hline$\underset{1}{2}$ & $\stackrel{\infty}{\stackrel{\infty}{\sim}}$ & & 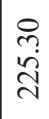 & $\frac{0}{n}$ & $\stackrel{8}{\circ}$ & 这 & $\stackrel{9}{\stackrel{9}{\prime}}$ & ठ̊. & 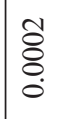 & 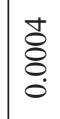 & 守 & $\underset{0}{ \pm}$ & 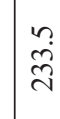 & $\begin{array}{l}0 \\
\dot{0} \\
-0\end{array}$ & 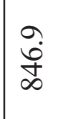 & $\begin{array}{l}1 \\
\widetilde{D} \\
0 \\
0 \\
-\end{array}$ \\
\hline$\vec{\infty}$ & $\begin{array}{l}2 \\
0 \\
\infty \\
\infty\end{array}$ & & तิ & $\stackrel{g}{\rightarrow}$ & $\stackrel{\overline{8}}{\circ}$ & ठิ & 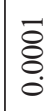 & ठ̊. & ठै. & ¿̊ & $\bar{\Xi}$ & 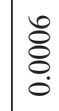 & $\ddot{n}$ & $\begin{array}{l}\circ \\
\stackrel{0}{0}\end{array}$ & $\begin{array}{l}\infty \\
\infty \\
\infty\end{array}$ & in \\
\hline 空 & ले & & $\begin{array}{l}\infty \\
\infty \\
i \\
i\end{array}$ & $\underset{\text { f }}{\text { f }}$ & $\overline{8}$ & $\tilde{\delta}$ & ڤ̊ & 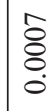 & ठ̊. & $\begin{array}{l}n \\
\vdots \\
\vdots \\
0 \\
0 \\
0\end{array}$ & $\stackrel{\infty}{\circ}$ & $\underset{\infty}{\stackrel{\infty}{0}}$ & ले & $\begin{array}{l}\tilde{y} \\
\dot{w}\end{array}$ & $\begin{array}{l}\tilde{N} \\
\underset{n}{\infty}\end{array}$ & 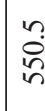 \\
\hline 忘 & 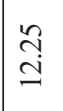 & & $\begin{array}{l}\stackrel{N}{\hat{D}} \\
-\end{array}$ & $\stackrel{2}{i}$ & $\bar{\Xi}$ & 嗃 & ठै. & $\frac{n}{8}$ & ठ̊. & ठิ & $\stackrel{\infty}{\stackrel{\infty}{0}}$ & $\frac{0}{\frac{0}{0}}$ & $\stackrel{\partial}{\infty}$ & ڤे & m. & 苛 \\
\hline$\sum_{\xi}$ & $\stackrel{\infty}{\stackrel{\infty}{=}}$ & & $\stackrel{n}{n}$ & $\stackrel{\infty}{=}$ & 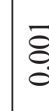 & $\vec{\Xi}$ & ठै. & $\overline{8}$ & ठ̊. & $\begin{array}{l}0 \\
\vdots \\
\vdots \\
\vdots \\
0\end{array}$ & ¿̊̀ & 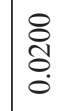 & $\stackrel{0}{\circ}$ & 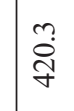 & $\begin{array}{l}0 \\
\stackrel{8}{+} \\
\stackrel{5}{8}\end{array}$ & $\frac{0}{\sqrt{3}}$ \\
\hline$\sum_{\xi}^{1}$ & $\stackrel{\infty}{=}$ & & 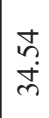 & $\stackrel{\bullet}{\infty}$ & $\bar{\Xi}$ & 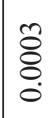 & 苂 & ఫิ & ठิ & 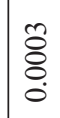 & $\frac{\partial}{\partial}$ & $\mid \begin{array}{c}0 \\
\stackrel{m}{0} \\
0\end{array}$ & $\begin{array}{l}0 \\
\dot{8} \\
\text { in }\end{array}$ & $\frac{\substack{\alpha \\
\alpha}}{\infty}$ & $\begin{array}{l}8 \\
\text { +े } \\
\text { in }\end{array}$ & 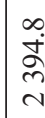 \\
\hline 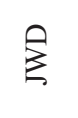 & $\begin{array}{l}\mathbb{I} \\
\mathbb{I} \\
\end{array}$ & $\begin{array}{l}\frac{\Xi}{5} \\
\Xi 0 \\
\Xi\end{array}$ & 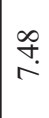 & 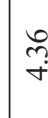 & $\bar{\Xi}$ & $\vec{\Xi}$ & 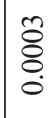 & ठิ & ठ̊. & 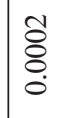 & ठ̊. & $\stackrel{8}{\circ}$ & $\cong$ & $\underset{m}{\stackrel{D}{c}}$ & 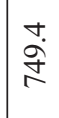 & $\stackrel{n}{\stackrel{n}{ \pm}}$ \\
\hline 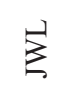 & $\underset{\sigma}{\sigma}$ & & $\stackrel{2}{2}$ & $\stackrel{\overbrace{}}{=}$ & $\bar{\Xi}$ & 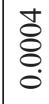 & छे. & ठ̊. & 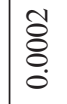 & $\bar{\circ}$ & ô. & $\mid \begin{array}{l}0 \\
0 \\
0 \\
0 \\
0\end{array}$ & ֶ. & $\overrightarrow{⿱ 宀 亠 凶 禸 ~}$ & \begin{tabular}{l}
$n$ \\
\multirow{2}{*}{} \\
¿
\end{tabular} & \begin{tabular}{l}
0 \\
\multirow{2}{n}{} \\
-
\end{tabular} \\
\hline$\frac{\theta}{\infty}$ & $\begin{array}{l}\infty \\
2 \\
2 \\
a\end{array}$ & & 总 & $\stackrel{\infty}{\sim}$ & ¿ & 㒸 & ठิ & 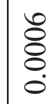 & $\begin{array}{l}\text { ठे } \\
\text {. }\end{array}$ & $\begin{array}{l}\tilde{\delta} \\
\text { oे } \\
0\end{array}$ & 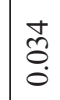 & $\bar{\delta}$ & $\stackrel{\bullet}{ }$ & $\begin{array}{l}\infty \\
\stackrel{\leftrightarrow}{\sim} \\
\stackrel{y}{1}\end{array}$ & $\stackrel{9}{r}$ & 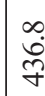 \\
\hline$\vec{\theta}$ & בิ & & 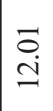 & $\stackrel{+}{3}$ & $\bar{\Xi}$ & 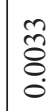 & $\overline{8}$ & $\mid \begin{array}{l}2 \\
\vdots \\
0 \\
\dot{0}\end{array}$ & $\begin{array}{l}\text { ठิ } \\
\text { ¿ }\end{array}$ & $\begin{array}{l}\text { ồ } \\
\text { } \\
0\end{array}$ & $\begin{array}{l}\text { fo } \\
\text { O } \\
0\end{array}$ & 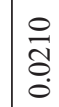 & 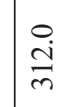 & $\begin{array}{l}\stackrel{0}{\mathrm{~d}} \\
\stackrel{\mathrm{N}}{\mathbf{n}}\end{array}$ & $\underset{\infty}{+\infty}$ & $\stackrel{ \pm}{\sim}$ \\
\hline$\hat{3}$ & $\mid \begin{array}{c}\hat{3} \\
\infty\end{array}$ & & $\frac{\Omega}{\Omega}$ & iे & $\overline{8}$ & $\stackrel{2}{\Xi}$ & $\stackrel{8}{\circ}$ & 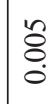 & ठ̊. & 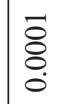 & 告 & 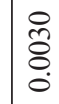 & $\stackrel{\gamma}{\dot{\gamma}}$ & $\begin{array}{l}0 \\
\dot{d} \\
\approx \\
q\end{array}$ & $\dot{\ddot{g}}$ & 尔 \\
\hline$\stackrel{\forall}{3}$ & $\frac{\infty}{a}$ & & $\frac{m}{2}$ & $\stackrel{\infty}{\stackrel{\infty}{a}}$ & $\bar{\Xi}$ & 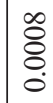 & $\stackrel{n}{8}$ & ठ̊. & 灾 & 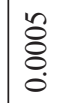 & $\tilde{\delta}$ & 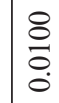 & 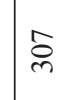 & $\begin{array}{l}\stackrel{2}{2} \\
2 \\
2\end{array}$ & $\hat{\infty}$ & ?. \\
\hline$\hat{\theta}$ & $\underset{\infty}{\stackrel{2}{\infty}}$ & & 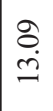 & $\begin{array}{l}\tilde{n} \\
\stackrel{3}{\beth}\end{array}$ & $\overline{8}$ & ồ & 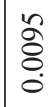 & 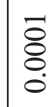 & 守 & 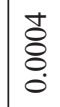 & 蒿 & 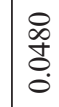 & $\hat{i}$ & $\begin{array}{l}\vec{\infty} \\
\stackrel{\infty}{+}\end{array}$ & 望 & $\stackrel{\circ}{\stackrel{\circ}{+}}$ \\
\hline 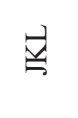 & $\frac{\partial}{\sigma}$ & & 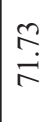 & $\begin{array}{l}\mathscr{\infty} \\
\stackrel{\Xi}{\sim}\end{array}$ & ঃ̊ & 官 & ठै. & ठิ & 范 & 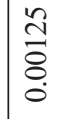 & ô. & đั) & ন & 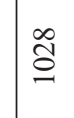 & $\begin{array}{l}0 \\
0 \\
\infty\end{array}$ & $\widehat{\widehat{\Xi}}$ \\
\hline 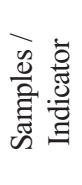 & $\bar{z}$ & $\begin{array}{l}\text { : } \\
\text { छั } \\
\text { : }\end{array}$ & $\bar{z}$ & \pm & $\Sigma$ & $\tilde{U}$ & $\frac{y}{z}$ & $\frac{0}{2}$ & 管地 & $\tilde{0}$ & U & $\frac{1}{2}$ & $\frac{1}{\sigma}$ & $\mathscr{O}^{+}$ & 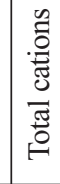 & 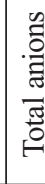 \\
\hline
\end{tabular}


tant tests: leaching and radionuclide content. This is the basis for the initiation of technological research to determine the specific directions of use of such wastes.

In several cases exceeding the limits were found (especially in terms of $\mathrm{pH}$ and sulphate content), which is typical also for some of the energy waste generated in the Polish power plants. These are not completely disqualifying features of that waste from the possibility of its use since there are methods known to reduce environmental risks in this area, particularly in the mining industry. It should be noted, however, that there is virtually no possibility of using fly ash with a high carbon content (and thus high loss on ignition), in the most popular directions as construction or mining, without additional processing.

During the studies large differences were found in the properties of the tested ash, especially in terms of their chemical composition and leaching. Analysis of the results indicates that the type of thermal process in which the ash is formed has a significant influence on their properties, followed by such factors as the type of ash and coal from which it originates.

Our studies did not identify a potential environmental hazard of tested materials significantly larger than from ash generated in coal combustion in power plants. However, exceeding the permissible limits, in some cases, indicates a need for further, regular testing of this type of ash. It is necessary to continue this type of research for both definition of the scope of variability of properties relevant to determine the impact on the environment, as well as further analysis of the observed relationships. Such studies should be performed for different types and process parameters as well as type of fuel.

\section{Acknowledgements}

Tests were carried out in the laboratories of $\mathrm{AGH}$ University of Science and Technology, in the faculties of: Mining and Geoengineering, Physics and Applied Computer Science as well as Geology, Geophysics, and Environmental Protection.

Work was performed under the task of research No. 3, "Development of coal gasification technology for high production of fuels and electricity," funded by the National Centre for Research and Development within the strategic program of research and development: "Advanced energy generation technologies.” Agreement NCBiR No. SP/E/3/ 7708/10.

\section{References}

1. BELVISO C., CAVALCANTE F., DI GENNARO S., PALMA A., RAGONE P., FIORE S. Mobility of trace elements in fly ash and in zeolitised coal fly ash. Fuel, 144, 369, 2015.

2. SIVULA L., OIKARI A., RINTALA J. Toxicity of waste gasification bottom ash leachate. Waste Manage. 32, (6), 1171, 2012.

3. ECKE H., ABERG A. Quantification of the effects of environmental leaching factors on emissions from bottom ash in road construction. Sci. Total Environ, 362, (1-3), 42, 2006.
4. TURHAN S., PARMAKSIZ A., KÖSE A., YÜKSEL A., ARIKAN İH., YÜCEL B. Radiological characteristics of pulverized fly ashes produced in Turkish coal-burning thermal power plants. Fuel, 89, (12), 3892, 2010.

5. NISNEVICH M., SIROTIN G., SCHLESINGER T., ESHEL Y. Radiological safety aspects of utilizing coal ashes for production of lightweight concrete. Fuel, 87, (8), 1610, 2008.

6. PIOTROWSKI Z. Utilization of fine-grained waste in underground coal mining). Archives of Mining Sciences: Monograph, No. 12, 2010 [In Polish].

7. AHMARUZZAMAN M. A review on the utilization of fly ash. Prog. Energ. Combust. 36, (3), 327, 2010.

8. HIGMAN C. State of the Gasification Industry - the Updated Worldwide Gasification Database. In: Proc. Gasification Technologies Conf., Colorado Springs, 2013.

9. CHMIELNIAK T., TOMASZEWICZ G. Gasification of solid fuels - the actual state and expected directions of development. Karbo, 3, 191, 2012 [In Polish].

10. eds. BOROWIECKI T., KIJEŃSKI J., MACHNIKOWSKI J., ŚCIĄŻKO M. Clean energy, chemical products and fuels from coal - Assessment of development potential, Institute for Chemical Processing of Coal IChPW, Zabrze, 2008 [In Polish].

11. ŚCIĄŻKO M., KUBICA K. The effect of dolomite addition on sulphur, chlorine and hydrocarbons distribution in a fluid-bed mild gasification of coal. Fuel Process. Technol. 77-78, 95, 2002.

12. CHMIELNIAK T., ŚCIĄŻKO M., SOBOLEWSKI A., TOMASZEWICZ G., POPOWICZ J. Coal gasification with $\mathrm{CO}_{2}$ as Gasification agent - as a method for improving emission factors and process efficiency. Polityka Energ. 15, (4), 125, 2012 [In Polish].

13. CHMIELNIAK T, SCIĄŻKO M, TOMASZEWICZ G, TOMASZEWICZ M. Pressurized $\mathrm{CO}_{2}$-enhanced gasification of coal: thermodynamical and kinetic modeling. J Therm Anal Calorim. 2014.

14. BŁASZCZUK A., KOMOROWSKI M., NALEWAJKA M. Temperature distribution and pressure fluctuations during biomass combustion in circulating fluidized bed. In: STACHEL A.A., MIKIELEWICZ D., eds. Proceedings of the $13^{\text {th }}$ International Symposium on Heat Transfer and Renewable Sources of Energy, pp. 15-24, 2010.

15. PORADA S., CZERSKI G., DZIOK T., GRZYWACZ P., MAKOWSKA D. Comparison of steam gasification kinetics of coal and its char. Przem Chem. 93, (12), 2059, 2014.

16. PORADA S., CZERSKI G., DZIOK T., GRZYWACZ P., MAKOWSKA D. Kinetics of steam gasification of bituminous coals in terms of their use of underground coal gasification. Fuel Process. Technol. 130, 282, 2015.

17. JO H.Y., MIN S-H., LEE T-Y., AHN H-S., LEE S-H., HONG J-K. Environmental feasibility of using coal ash as a fill material to raise the ground level. J Hazard Mater. 154, (1-3), 933, 2008.

18. LEMLY A.D. An urgent need for an EPA standard for disposal of coal ash. Environ Pollut. 191, 253, 2014.

19. VAMVUKA D., KAKARAS E. Ash properties and environmental impact of various biomass and coal fuels and their blends. Fuel Process. Technol. 92, (3), 570, 2011.

20. SINGH S., RAM L.C., MASTO R.E., VERMA S.K. A comparative evaluation of minerals and trace elements in the ashes from lignite, coal refuse, and biomass fired power plants. Int. J. Coal Geol. 87, (2), 112, 2011. 
21. TSIRIDIS V., PETALA M., SAMARAS P., KUNGOLOS A., SAKELLAROPOULOS G.P. Environmental hazard assessment of coal fly ashes using leaching and ecotoxicity tests. Ecotox. Environ. Safe. 84, 212, 2012.

22. MENÉNDEZ E., ÁLVARO A.M., HERNÁNDEZ M.T., PARRA J.L. New methodology for assessing the environmental burden of cement mortars with partial replacement of coal bottom ash and fly ash. J. Environ. Manage. 133, 275, 2014.

23. GARRABRANTS A.C., KOSSON D.S., DELAPP R., Van der SLOOT H.A. Effect of coal combustion fly ash use in concrete on the mass transport release of constituents of potential concern. Chemosphere. 103, 131, 2014.

24. NAYAK A.K., RAJA R., RAO K.S., SHUKLAA.K., SANGITA M., SHAHID M., TRIPATHI R., PANDAA B.B., BHATTACHARYYA P., KUMARA A., LAL BSETHI S.K., PURI C., NAYAK D., SWAIN C.K. Effect of fly ash application on soil microbial response and heavy metal accumulation in soil and rice plant. Ecotox. Environ. Safe. 114, 257, 2014.

25. IZQUIERDO M., QUEROL X. Leaching behaviour of elements from coal combustion fly ash: An overview. Int. J. Coal Geol. 94, 54, 2012.

26. TRYBALSKI K., KĘPYS W., KRAWCZYKOWSKI D., KRAWCZYKOWSKA A., SZPONDER D. Physical Properties of Ash from Co-Combustion of Coal and Biomass. Pol. J. Environ. Stud. 23, (4), 1433, 2014.

27. TRYBALSKI K., KĘPYS W., KRAWCZYKOWSKA A., KRAWCZYKOWSKI D., SZPONDER D. Co-Combustion of Coal and Biomass - Chemical Properties of Ash. Pol. J. Environ. Stud. 23, (4), 1427, 2014.

28. DINH CHAU N., DULINSKI M., JODLOWSKI P., NOWAK J., ROZANSKI K., SLEZIAK M., WACHNIEW P. Natural radioactivity in groundwater - a review. Isot. Environ. Healt. S. 47, (4), 415, 2011.

29. GRAMMELIS P., SKODRAS G., KAKARAS E., KARANGELOS D., PETROPOULOS N., ANAGNOSTAKIS M., HINIS E., SIMOPOULOS S. Effects of biomass co-firing with coal on ash properties. Part II: Leaching, toxicity and radiological behaviour. Fuel $\mathbf{8 5}$, (16), 2316, 2006.

30. TSO M.W., LEUNG J.K.C. Radiological impact of coal ash from the power plants in Hong Kong. J. Environ. Radioactiv. 30, (1), 1, 1996.

31. KARANGELOS D.J., PETROPOULOS N.P., ANAGNOSTAKIS M.J., HINIS E.P., SIMOPOULOS S.E. Radiological characteristics and investigation of the radioactive equilibri$\mathrm{um}$ in the ashes produced in lignite-fired power plants. $\mathrm{J}$ Environ. Radioactiv. 77, (3), 233, 2004.
32. POMYKAŁA R. Properties of Waste from Coal Gasification in Entrained Flow Reactors in the Aspect of Their Use in Mining Technology. Arch Min Sci. 58, (2), 375, 2013.

33. KALEMBKIEWICZ J., CHMIELARZ U. Ashes from cocombustion of coal and biomass: New industrial wastes. Resour. Conserv. Recy. 69, 109, 2012.

34. MOUSTAKAS K., MAVROPOULOS A., KATSOU E., HARALAMBOUS K.J., LOIZIDOU M. Leaching properties of slag generated by a gasification/vitrification unit: the role of $\mathrm{pH}$, particle size, contact time and cooling method used. J. Hazard. Mater. 207-208, 44, 2012.

35. HARDIN C.D., SWEENEY C.R., MIESFELDT M. Summary of the EPA's Leaching Environmental Assessment Framework (LEAF) and the Implications for Coal Ash Impoundments and Beneficial Use in Mine Reclamation Implications for Coal Ash Reuse. Proc. World of Coal Ash (WOCA) Conference, 2011.

36. POMYKAŁA R., KĘPYS W., ŁYKO P. Effect of Temperature and Cement Additive on Setting Time of Fly Ash-water Suspensions. Rocz Ochr Środowiska. 15, (2), 1818, 2013 [In Polish].

37. PIOTROWSKI Z., POMYKALA R., KANAFEK J. The utilization of energy waste in Polish underground coalmines. In: Proc. World of Coal Ash (WOCA) Conference, 2009.

38. TURHAN Ş., ARIKAN İH., YÜCEL B., VARINLIOĞLU A., KÖSE A. Evaluation of the radiological safety aspects of utilization of Turkish coal combustion fly ash in concrete production. Fuel. 89, (9), 2528, 2010.

39. BASU M., PANDE M., BHADORIA P.B.S., MAHAPATRA S.C. Potential fly-ash utilization in agriculture: A global review. Prog Nat Sci. 19, (10), 1173, 2009.

40. MIANOWSKI A, RADKO T, POLAŃSKI J. Usability of fly ash with a high content of $\mathrm{C}$ element in the production of building ceramics. Szkło i Ceram. 3, 23, 1991 [In Polish].

41. WU T., GONG M., LESTER E., WANG F., ZHOU Z., YU $Z$. Characterisation of residual carbon from entrained-bed coal water slurry gasifiers. Fuel. 86, (7-8), 972, 2007.

42. GU J., WU S., WU Y., LI Y., GAO J. Differences in Gasification Behaviors and Related Properties between Entrained Gasifier Fly Ash and Coal Char. Energ. Fuel. 22, 4029, 2008.

43. SISOL M., DRABOVA M., MOSEJ J. Alkali activation of fresh and deposited black coal ash with high loss on ignition. Gospod Surowcami Miner - Miner Resour Manag, 30, (2), 103, 2014.

44. POMYKAŁA R. Preliminary Characteristic Of Coal Gasification By-Product From Pilot Plants Based On Fluidized Bed Reactors. In: International Pittsburgh Coal Conference. Beijing, 2013. 
